\title{
The Role of Halogen Bonding in Crystal Structures of 3-Halogeno Cytisine Derivatives
}

\author{
Anna K. Przybył · Maciej Kubicki
}

Received: 29 November 2011 / Accepted: 14 February 2012/Published online: 3 March 2012

(C) The Author(s) 2012. This article is published with open access at Springerlink.com

\begin{abstract}
The crystal structures of three 3-halogeno derivatives of $13 \mathrm{~N}$-substituted cytisine have been determined by X-ray diffraction. The two 13-acetyl substituted compounds, 3-bromo (1) and 3-iodo (2) are isostructural, with the isostructurality index as high as $99 \%$. They both crystallize in monoclinic $P 2_{1}$ space group, with unit cell parameters of $a=8.4709(10) \AA, b=9.2266(12) \AA, c=$ 8.6051(10) $\AA, \beta=98.528(11)^{\circ}(\mathbf{1})$ and $a=8.2322(6) \AA$, $b=9.1724(7) \AA, c=8.5494(6) \AA, \beta=98.181(7)^{\circ}$ (2). In turn, 3-bromo-13-t-butyl-carbonate derivative (3) crystallizes in orthorhombic $P 22_{1} 2_{1} 2_{1}$ space group with $a=$ 6.8171(3) ̊, $b=7.8994(4) \AA, c=31.4657(15) \AA$. Conformation of the cytisine skeleton is similar in all three molecules, with almost planar A ring, sofa conformation of $\mathrm{B}$-ring and $\mathrm{C}$ ring being an almost ideal chair. However, the orientations of the double $\mathrm{C}=\mathrm{O}$ bonds in $13 \mathrm{~N}$-substituents are completely different: in $\mathbf{1}$ and $\mathbf{2}$ it is cis with respect to $\mathrm{C} 12\left(\mathrm{C} 12-\mathrm{N} 13-\mathrm{C} 14-\mathrm{O} 15\right.$ torsion angle is $3.3(4)^{\circ}$ in $\mathbf{1}$ and $1.3(6)^{\circ}$ in $\left.\mathbf{2}\right)$ while in $\mathbf{3}$ it is trans $\left(-175.4(3)^{\circ}\right)$. In the structures of $\mathbf{1}$ and $\mathbf{2}$ the driving force of the crystal architecture are quite strong $\mathrm{C}-\mathrm{H} \cdots \mathrm{X}$ halogen bonds with $\mathrm{C} \cdots \mathrm{X}$ distances far shorter than the sums of van der Waals

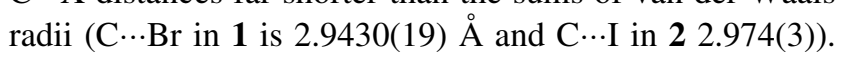
In contrast in 3-partially as the consequence of different orientation of the substituent-there are no halogen bondings but instead some weak $\mathrm{C}-\mathrm{H} \cdots \mathrm{O}$ contacts organize the molecules into two-dimensional patterns.
\end{abstract}

Keywords Cytisine - Isostructuralism - Conformation · Halogen bonding $\cdot$ Crystal structure

A. K. Przybył · M. Kubicki $(\bowtie)$

Department of Chemistry, Faculty of Chemistry, Adam

Mickiewicz University, Grunwaldzka 6, 60-780 Poznań, Poland

e-mail: mkubicki@amu.edu.pl

\section{Introduction}

Cytisine is a natural quinolizidine alkaloid found in Fabacea plants such as Cytisus laburnum and Laburnum anagyroides [1].

For many years cytisine has been used for smoking cessation in central and eastern European countries [2, 3]. It is a partial agonist at the $\alpha 4 \beta 2 \mathrm{nAChR}$. Cytisine also shows high affinity for other nAChR subtypes, but the therapeutic consequence of them is unknown. These receptors have been identified as promising targets for the treatment of several neurological disorders, such as Parkinson's and Alzheimer's diseases, Tourette's syndrome, dyskinesias, schizophrenia, anxiety, attention deficit disorder, and pain [4-6]. Additionally, this natural compound was found to decrease nicotine-induced extra cellular dopamine release in the nucleus accumbens [7], and was shown to reduce ethanol drinking behaviors in mice or rats $[8,9]$ and ethanol-induced dopamine and its metabolite [10]. Therefore, nicotinic ligands could be developed as potential therapeutic candidates for binge-like ethanol drinking and dependence in humans.

Recent interest in the chemistry of cytisine (1) has been growing because of a lack of understanding as to the molecular basis of this underpinning partial agonist profile. In terms of analogues, manipulation of cytisine itself is readily achievable at $\mathrm{C} 3$ and $\mathrm{C} 5, \mathrm{C} 10$, and $\mathrm{N} 12$ [11-20] but interest in cytisine as a target for total synthesis has also been significant as well as the synthesis of cytisine derivatives [21, 22].

In this context, in the present work we have attempted to analyze the structures of cytisine derivatives halogenated at C3 position (Scheme 1): 3-bromo- $N$-acetylcytisine (1), 3-iodo- $\mathrm{N}$-acetylcytisine (2) and 3-bromo-cytisine-N-tbutylcarbonylate (N-boc-3bromocytisine) (3) [15, 23, 24]. 
This side is favorable for binding to $\alpha 4 \beta 2 \mathrm{nAChRs}$ [22]. We believe that together with biological research our work can help to understand how their structural differences are responsible for their ability to bind to nicotinic receptors and their different affinities.

\section{Results and Discussion}

Figures 1, 2 and 3 show the perspective view of the molecules 1-3, respectively. Table 1 lists some essential geometrical parameters.

Two acetyl derivatives $\mathbf{1}$ and $\mathbf{2}$ are isostructural. They crystallize in the same space groups, the unit cells are very similar and the disposition of the molecules in the crystal structure is almost identical. The values of the indicators of isostructurality introduced by Kalman et al. [25] and<smiles>[X]c1ccc2n(c1=O)C[C@H]1C[C@H]2CN([R])C1</smiles>

1: $\mathrm{X}=\mathrm{Br}, \mathrm{R}=\mathrm{COCH}_{3}$

2: $X=I, \quad R=\mathrm{COCH}_{3}$

3: $\mathrm{X}=\mathrm{Br}, \mathrm{R}=\mathrm{COO}\left({ }^{\mathrm{t}} \mathrm{Bu}\right)$

Scheme 1 The formulae of compounds 1-3

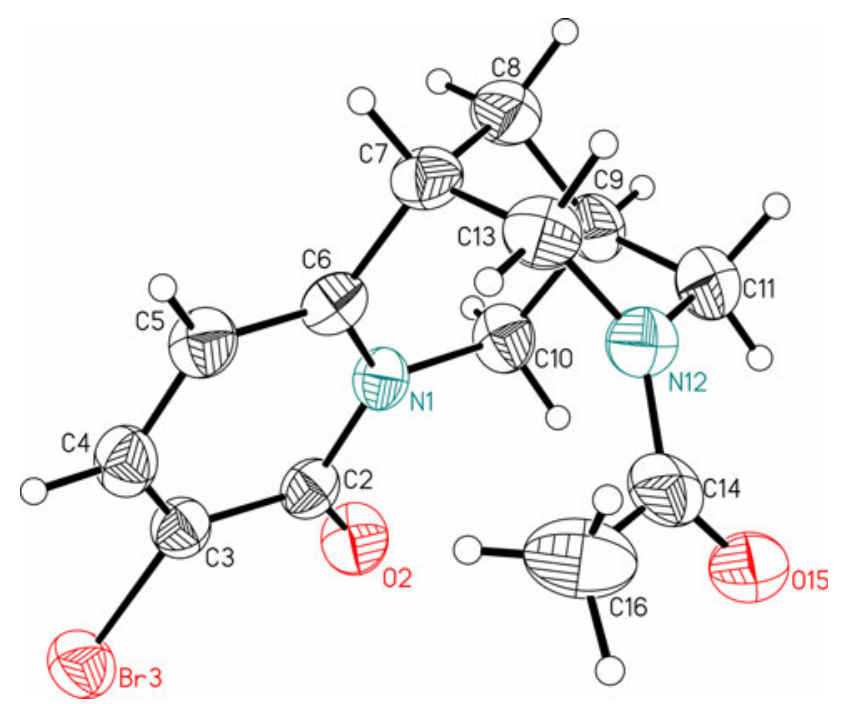

Fig. 1 Ellipsoid representation of molecule 1 together with the atom labeling scheme. The ellipsoids are drawn at $50 \%$ probability level, hydrogen atoms are depicted as spheres with arbitrary radii modified by Szafrański and Kubicki [26] show that in this case the degree of isostructurality is very high. The isostructurality index which describes in principle the mean difference between the positions of analogous atoms in the

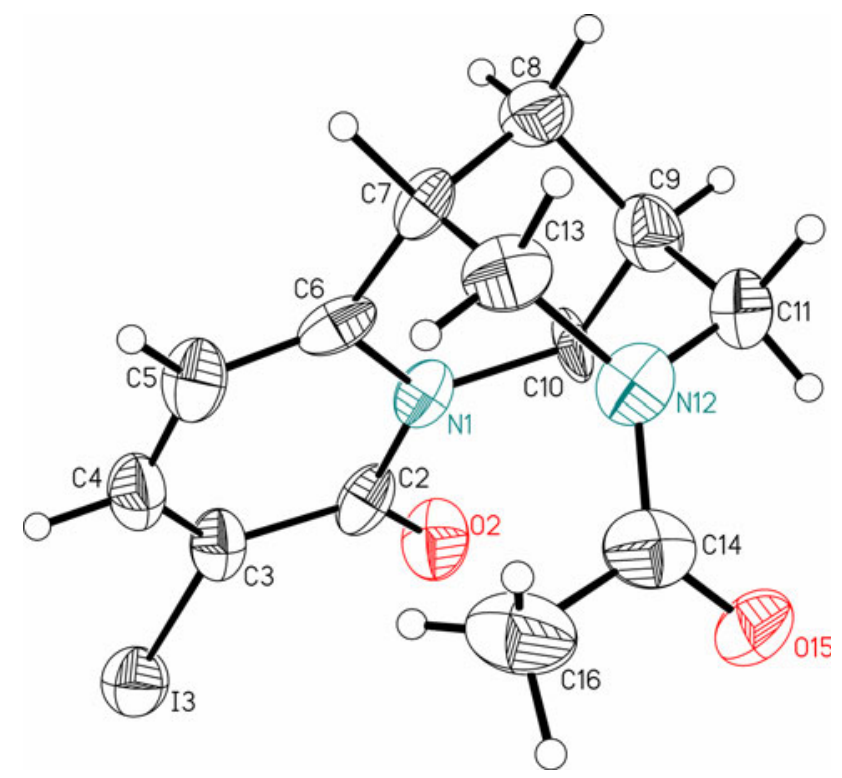

Fig. 2 Ellipsoid representation of molecule 2 together with the atom labeling scheme. The ellipsoids are drawn at $50 \%$ probability level, hydrogen atoms are depicted as spheres with arbitrary radii

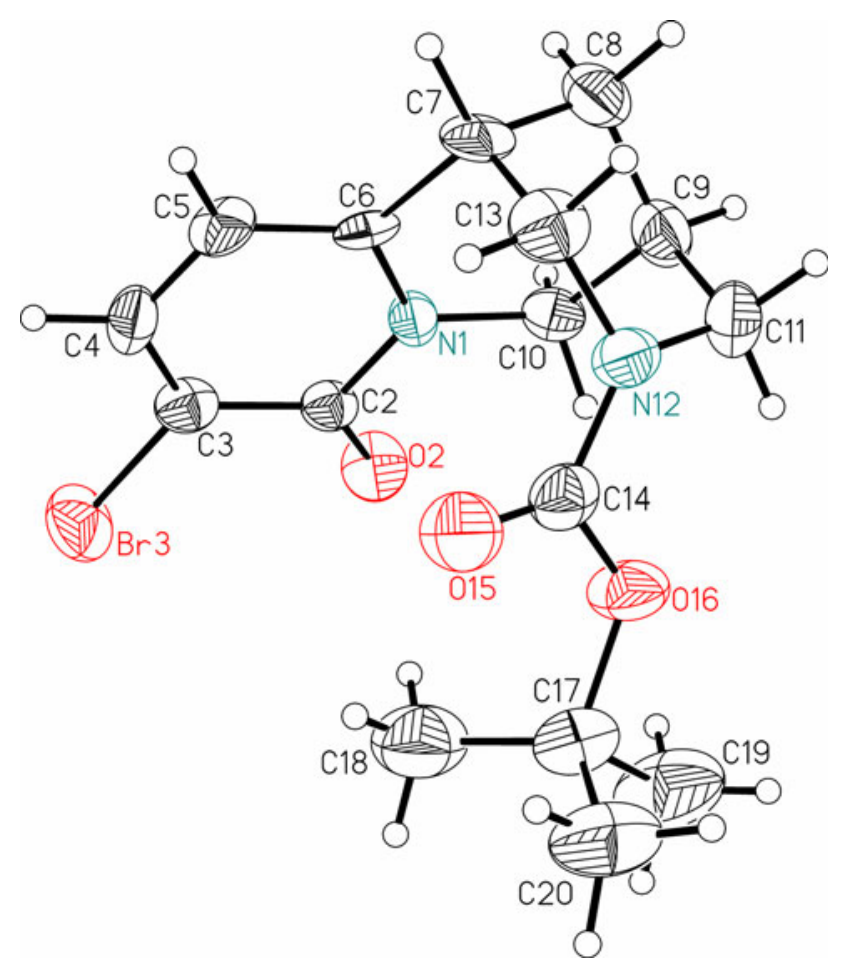

Fig. 3 Ellipsoid representation of molecule 3 together with the atom labeling scheme. The ellipsoids are drawn at $50 \%$ probability level, hydrogen atoms are depicted as spheres with arbitrary radii 
Table 1 Selected geometrical data $\left(\AA{ }^{\circ}\right)$ with su's in parentheses

\begin{tabular}{llll}
\hline & $\mathbf{1}$ & $\mathbf{2}$ & $\mathbf{3}$ \\
\hline $\mathrm{N} 1-\mathrm{C} 2$ & $1.407(3)$ & $1.411(5)$ & $1.419(4)$ \\
$\mathrm{N} 1-\mathrm{C} 6$ & $1.378(4)$ & $1.418(8)$ & $1.363(4)$ \\
$\mathrm{C} 2-\mathrm{O} 2$ & $1.229(3)$ & $1.211(5)$ & $1.213(3)$ \\
$\mathrm{C} 2-\mathrm{C} 3$ & $1.445(4)$ & $1.452(8)$ & $1.453(3)$ \\
$\mathrm{C} 3-\mathrm{C} 4$ & $1.352(4)$ & $1.331(8)$ & $1.326(3)$ \\
$\mathrm{C} 3-\mathrm{Br} 3$ & $1.885(2)$ & & $1.889(3)$ \\
$\mathrm{C} 3-\mathrm{I3}$ & & $2.082(3)$ & \\
$\mathrm{N} 12-\mathrm{C} 13$ & $1.460(4)$ & $1.463(5)$ & $1.451(3)$ \\
$\mathrm{N} 12-\mathrm{C} 11$ & $1.464(4)$ & $1.450(5)$ & $1.464(3)$ \\
$\mathrm{N} 12-\mathrm{C} 14$ & $1.356(4)$ & $1.359(6)$ & $1.354(4)$ \\
$\mathrm{C} 14-\mathrm{O} 15$ & $1.228(4)$ & $1.210(6)$ & $1.210(3)$ \\
$\mathrm{C} 6-\mathrm{N} 1-\mathrm{C} 2$ & $123.7(2)$ & $121.5(4)$ & $125.0(2)$ \\
$\mathrm{C} 6-\mathrm{N} 1-\mathrm{C} 10$ & $122.4(2)$ & $125.7(4)$ & $123.7(3)$ \\
$\mathrm{C} 2-\mathrm{N} 1-\mathrm{C} 10$ & $113.7(2)$ & $112.4(3)$ & $110.6(3)$ \\
$\mathrm{C} 11-\mathrm{N} 12-\mathrm{C} 13$ & $113.9(2)$ & $114.4(4)$ & $113.3(3)$ \\
$\mathrm{C} 11-\mathrm{N} 12-\mathrm{C} 14$ & $120.6(2)$ & $120.3(4)$ & $124.5(3)$ \\
$\mathrm{C} 13-\mathrm{N} 12-\mathrm{C} 14$ & $125.5(2)$ & $125.3(4)$ & $119.3(3)$ \\
C9-C11-N12-C14 & $122.8(3)$ & $123.7(4)$ & $105.2(4)$ \\
$\mathrm{C} 11-\mathrm{N} 12-\mathrm{C} 14-\mathrm{O} 15$ & $3.3(4)$ & $1.9(7)$ & $-175.4(3)$ \\
C11-N12-C14-C16 & $-176.6(3)$ & $-177.9(4)$ & $6.3(4)$ \\
$\mathrm{C} 11-\mathrm{N} 12-\mathrm{C} 14-\mathrm{O} 16$ & &
\end{tabular}

Table 2 Intermolecular interaction data $\left(\AA,{ }^{\circ}\right)$ with su's in parentheses

\begin{tabular}{lllllll}
\hline $\mathbf{1}$ & & & & & & \\
$\mathrm{C}$ & $\mathrm{X}$ & $\mathrm{O}$ & $\mathrm{C}-\mathrm{X}$ & $\mathrm{X} \cdots \mathrm{O}$ & $\mathrm{C}-\mathrm{X} \cdots \mathrm{O}$ & $\mathrm{X} \cdots \mathrm{O}=\mathrm{C}$ \\
$\mathrm{C} 3$ & $\mathrm{Br3}$ & ${\mathrm{O} 15^{\mathrm{a}}}$ & $1.885(2)$ & $2.9430(19)$ & $170.18(11)$ & $108.64(16)$ \\
$\mathbf{2}$ & & & & & & \\
$\mathrm{C}$ & $\mathrm{X}$ & $\mathrm{O}$ & $\mathrm{C}-\mathrm{X}$ & $\mathrm{X} \cdots \mathrm{O}$ & $\mathrm{C}-\mathrm{X} \cdots \mathrm{O}$ & $\mathrm{X} \cdots \mathrm{O}=\mathrm{C}$ \\
$\mathrm{C} 3$ & $\mathrm{I} 3$ & $\mathrm{O} 15^{\mathrm{a}}$ & $12.083(3)$ & $2.974(3)$ & $170.91(16)$ & $110.2(3)$ \\
$\mathbf{3}$ & & & & & & \\
$\mathrm{D}$ & $\mathrm{H}$ & $\mathrm{A}$ & $\mathrm{D}-\mathrm{H}$ & $\mathrm{H} \cdots \mathrm{A}$ & $\mathrm{D} \cdots \mathrm{A}$ & $\mathrm{D}-\mathrm{H} \cdots \mathrm{A}$ \\
$\mathrm{C} 5$ & $\mathrm{H} 5$ & $\mathrm{Br} 3^{\mathrm{b}}$ & 0.93 & 3.16 & $4.035(3)$ & 159 \\
$\mathrm{C} 7$ & $\mathrm{H} 7$ & $\mathrm{O} 2^{\mathrm{b}}$ & 0.98 & 2.47 & $3.140(4)$ & 126 \\
$\mathrm{C} 13$ & $\mathrm{H} 13 \mathrm{a}$ & $\mathrm{O} 2^{\mathrm{b}}$ & 0.97 & 2.59 & $3.138(3)$ & 116 \\
$\mathrm{C} 9$ & $\mathrm{H} 9$ & $\mathrm{O} 15^{\mathrm{c}}$ & 0.98 & 2.51 & $3.287(3)$ & 136 \\
\hline
\end{tabular}

Symmetry codes: ${ }^{\mathrm{a}} 1-x,-1 / 2+y,-z ;{ }^{\mathrm{b}} x,-1+y, z ;{ }^{\mathrm{c}}-1+x, y, z$

unit cell is almost ideal, equals to $98.9 \%$. Of course, also the geometrical parameters of these two molecules are quite similar, so similar that in principle they make a good example for the application of the normal probability distribution test $[27,28]$, which shows how far the differences between two molecules can be described as statistical only. In this case the correlation coefficient $\mathrm{R}^{2}$ for bond lengths (without the $\mathrm{C}-\mathrm{X}$ bond) is 0.979 and for all bond angles -0.963 . The linear regression equations confirm the frequently described overestimation of the standard uncertainties by a factor of 2 .

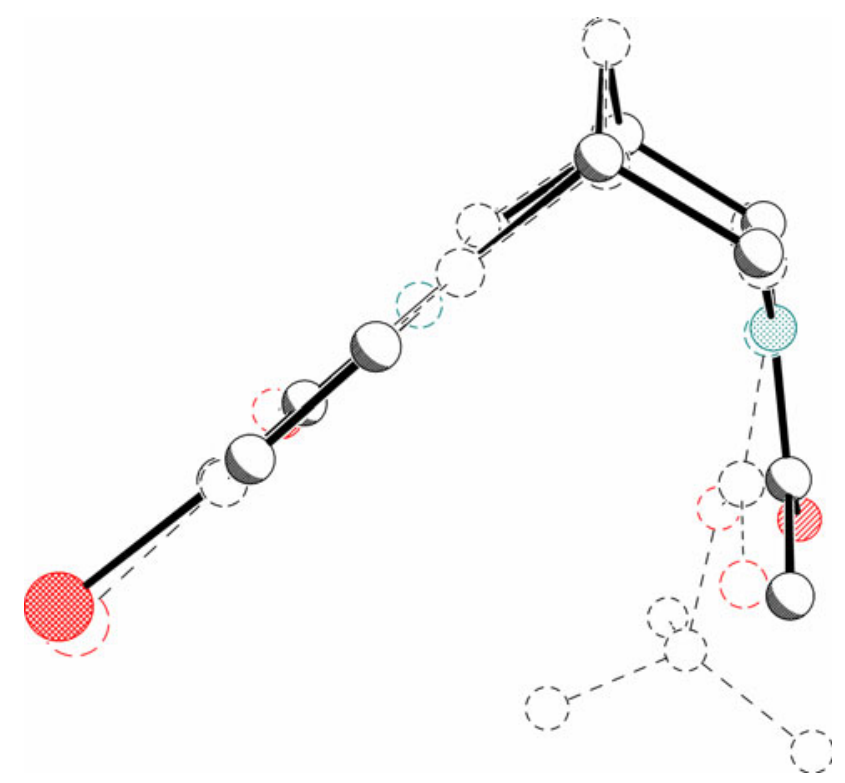

Fig. 4 The comparison of molecules $\mathbf{1}$ and $\mathbf{3}$ fitted onto their A rings (solid lines $\mathbf{- 1}$, dashed lines $\mathbf{- 3}$ )

Therefore in further analysis we will compare the 3-bromo-N-boc derivative (3) to 3-bromo-N-acyl derivative (1) only as 3-iodo- $\mathrm{N}$-acyl compound (2) is almost identical with $\mathbf{1}$.

Overall conformations of the molecules are quite similar; the cytisine skeleton is stiff and the rings have almost 
the same shape. Interestingly, it turns out that the protonation of cytosine does not change its conformation (cf. [23, 24]); such a change was observed in e.g. sparteine (for instance, [29, 30]) or multiflorine derivatives (e.g. [31, 32]).The ring A (cf. Fig. 1) is almost planar, maximum deviation from the least squares planes are 0.020(3) $\AA$ in $\mathbf{1}$, 0.006(2) $\AA$ in $\mathbf{2}$ and 0.033(2) $\AA$ in 3. Rings B are all close to the sofa conformation; the asymmetry parameters [33] which describe the deviations of these rings from their ideal $C_{s}$ symmetry are $3.3,5.8$ and $3.7^{\circ}$. Finally, the rings $\mathrm{C}$ are almost ideal chairs, with the appropriate asymmetry parameters $\Delta C_{s}$ and $\Delta C_{2}$ not larger than $5^{\circ}$.

Some conformational differences between 3 on one side and $\mathbf{1}$ and $\mathbf{2}$ on the other should be however noticed (Fig. 4), and it turns out that these slight changes mean a lot for the crystal packing. First, the overall shape of the molecules can be defined by the dihedral angle between planar ring A and an approximately planar fragment from another site of the molecule, which is the mean plane of the $\mathrm{C} 11, \mathrm{~N} 12, \mathrm{C} 13, \mathrm{C} 14, \mathrm{O} 15, \mathrm{C}(\mathrm{O}) 16$ fragment. This angle differs quite significantly, it is $44.33(8)^{\circ}$ in $\mathbf{3}$ and $55.50(9)^{\circ}$ in $1\left[56.57(14)^{\circ}\right.$ in 2]. Second, the orientation of the $\mathrm{C} 14=\mathrm{O} 15$ double bond is defined by e.g. the torsion angle C11-N12-C14-O15, and is completely different for $\mathbf{3}$ where it is $-175.4(3)^{\circ}$ (trans) and $\mathbf{1}$ where the orientation is cis-the value of the torsion angle is $3.3(4)^{\circ}\left[1.3(6)^{\circ}\right.$ in 2].

The crystal structures of compounds $\mathbf{3}$ on one side and $\mathbf{1}$ and $\mathbf{2}$ on the other are determined by quite different weak intermolecular interactions. This might be regarded as another example of the competition between weak hydrogen bonds and so-called halogen bonds, and this competition in the present case influences the conformation of a side chain. In 3 there are some weak $\mathrm{C}-\mathrm{H} \cdots \mathrm{O}$ interactions (Table 3), which organize molecules into a two-dimensional pattern (Fig. 5). These interactions are weak, as
Table 3 Crystal data, data collection and structure refinement

\begin{tabular}{|c|c|c|c|}
\hline Compound & 1 & 2 & 3 \\
\hline Formula & $\mathrm{C}_{13} \mathrm{H}_{13} \mathrm{BrN}_{2} \mathrm{O}_{2}$ & $\mathrm{C}_{13} \mathrm{H}_{13} \mathrm{IN}_{2} \mathrm{O}_{2}$ & $\mathrm{C}_{16} \mathrm{H}_{21} \mathrm{BrN}_{2} \mathrm{O}_{3}$ \\
\hline Formula weight & 311.18 & $356.15 / \mathrm{c}$ & 369.26 \\
\hline Crystal system & Monoclinic & Monoclinic & Orthorhombic \\
\hline Space group & $P 2_{1}$ & $P 2_{1}$ & $P 2{ }_{1} 2_{1} 2_{1}$ \\
\hline $\mathrm{a}(\AA)$ & $8.2322(6)$ & $8.4709(10)$ & $6.8171(3)$ \\
\hline$b(\AA)$ & $9.1724(7)$ & $9.2266(12)$ & 7.8994(4) \\
\hline$c(\AA)$ & $8.5494(6)$ & $8.6051(10)$ & $31.4657(15)$ \\
\hline$\beta\left(^{\circ}\right)$ & $98.181(7)$ & $98.528(11)$ & 90 \\
\hline $\mathrm{V}\left(\AA^{3}\right)$ & $638.99(8)$ & $665.12(14)$ & $1694.46(14)$ \\
\hline $\mathrm{Z}$ & 2 & 2 & 4 \\
\hline $\mathrm{d}_{\mathrm{x}}\left(\mathrm{g} \mathrm{cm}^{-3}\right)$ & 1.62 & 1.78 & 1.45 \\
\hline $\mathrm{F}(000)$ & 316 & 348 & 760 \\
\hline$\mu\left(\mathrm{mm}^{-1}\right)$ & 3.21 & 2.40 & 2.44 \\
\hline$\Theta$ range $\left({ }^{0}\right)$ & $2.41-26.49$ & $3.26-29.00$ & $2.89-27.96$ \\
\hline hkl range & $\begin{array}{l}-10 \leq \mathrm{h} \leq 9 \\
-11 \leq \mathrm{k} \leq 11 \\
-10 \leq \mathrm{l} \leq 10\end{array}$ & $\begin{array}{l}-11 \leq \mathrm{h} \leq 10 \\
-12 \leq \mathrm{k} \leq 12 \\
-11 \leq \mathrm{l} \leq 11\end{array}$ & $\begin{array}{l}-8 \leq \mathrm{h} \leq 7 \\
-10 \leq \mathrm{k} \leq 4 \\
-41 \leq \mathrm{l} \leq 37\end{array}$ \\
\hline \multicolumn{4}{|l|}{ Reflections: } \\
\hline collected & 11482 & 10748 & 5768 \\
\hline Unique $\left(\mathrm{R}_{\text {int }}\right)$ & $2485(0.039)$ & $3161(0.049)$ & $3198(0.029)$ \\
\hline With $\mathrm{I}>2 \sigma(\mathrm{I})$ & 2224 & 2041 & 1947 \\
\hline No. of parameter & 164 & 164 & 202 \\
\hline \multicolumn{4}{|l|}{ Weighting scheme: } \\
\hline A & 0.03 & 0.01 & 0.006 \\
\hline Flack parameter [39] & $0.041(7)$ & $-0.003(8)$ & $-0.01(2)$ \\
\hline $\mathrm{R}(\mathrm{F})[\mathrm{I}>2 \sigma(\mathrm{I})]$ & 0.025 & 0.035 & 0.034 \\
\hline$w R\left(\mathrm{~F}^{2}\right)[\mathrm{I}>2 \sigma(\mathrm{I})]$ & 0.055 & 0.043 & 0.034 \\
\hline $\mathrm{R}(\mathrm{F})$ [all data] & 0.029 & 0.068 & 0.068 \\
\hline$w R\left(F^{2}\right)$ [all data] & 0.056 & 0.045 & 0.036 \\
\hline Goodness of fit & 1.111 & 0.990 & 0.911 \\
\hline $\operatorname{Max} / \min \Delta \rho\left(\mathrm{e}^{-3}\right)$ & $0.37 /-0.24$ & $1.09 /-0.61$ & $0.59 /-0.36$ \\
\hline
\end{tabular}




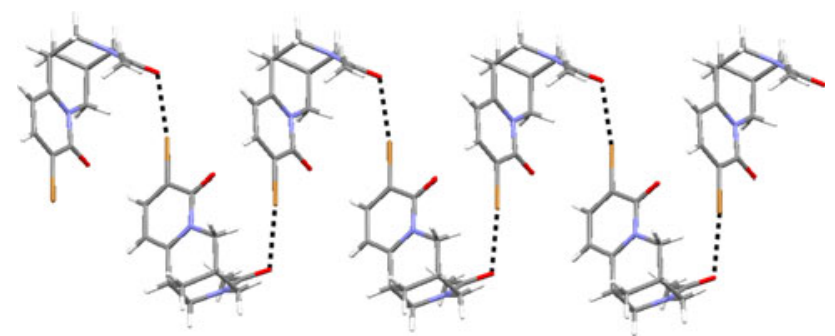

Fig. 5 The chain of molecules $\mathbf{1}$ connected by the relatively strong $\mathrm{C}-\mathrm{Br} \cdots \mathrm{O}$ halogen bonds (denoted as dashed lines)

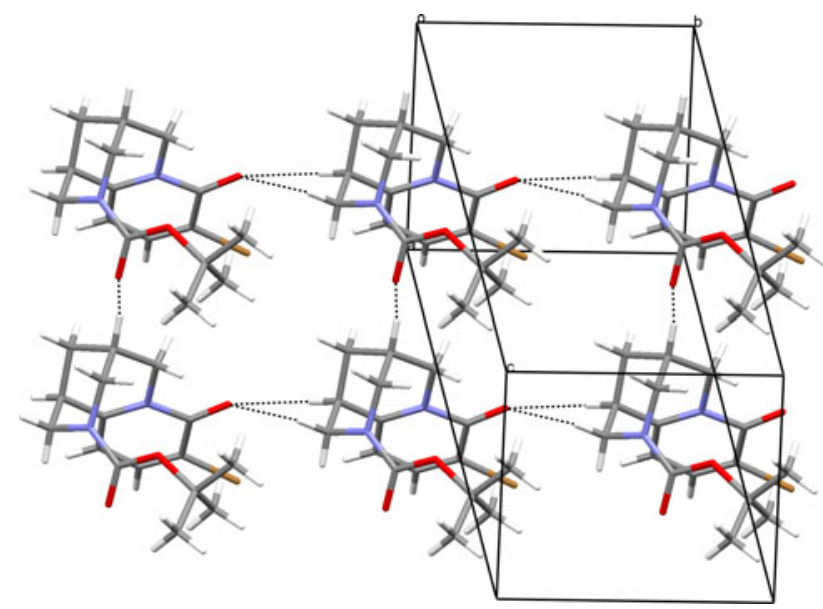

Fig. 6 The fragment of the crystal structure of $\mathbf{3}$; with weak $\mathrm{C}-\mathrm{H} \cdots \mathrm{O}$ hydrogen bonds (dashed lines)

judged by their geometrical characteristics, but-looking at the crystal structure-they undoubtedly influence the crystal structure. In the structures of $\mathbf{1}$ and $\mathbf{2}$ the driving force of the crystal architecture are quite strong $\mathrm{C}-\mathrm{H} \cdots \mathrm{X}$ halogen bonds ( $\mathrm{X}=\mathrm{Br}$ for $\mathbf{1}$, I for $\mathbf{2})$. This kind of interaction, postulated in the 1960s [34, 35] and confirmed as an important player in the determination of the crystal structure (e.g. $[36,37]$ and references therein), are in principle electrostatic interactions between a covalently bound halogen atom and the lone pair of the "acceptor" atom, and they should be quite directional. This is exactly the case in the crystal structures of $\mathbf{1}$ and $\mathbf{2}$, where the angles $\mathrm{C}-\mathrm{X} \cdots \mathrm{O}$ are close to $180^{\circ}$ while the angles $\mathrm{C}=\mathrm{O} \cdots \mathrm{X}$ suggest the direction of the lone pair of the oxygen atom (cf. Fig. 6; Table 2). These interactions are quite strong in $\mathbf{1}$ and $\mathbf{2}$. In the Cambridge Structural Database (CSD, [38], version 5.33 of Nov. 2011) we have found $832 \mathrm{C}-\mathrm{Br} \cdots \mathrm{O}$ contacts with $\mathrm{Br} \cdots \mathrm{O}$ distances closer than the sum of appropriate van der Waals radii as defined by the CSD, but only less than 50 of them are closer or comparable to the $\mathrm{Br} \cdots \mathrm{O}$ distance in 1 (2.9430(19) $\AA$ ). For iodine derivatives there are 337 fragments with $\mathrm{I} \cdots \mathrm{O}$ distances shorter than the sum of the van der Waals radii and only 40 closer than or equal to the distance in 2 (2.974(3) $\AA$ ).

\section{Experimental}

The synthetic procedure has been described elsewhere [15, $23,24]$. Crystals appropriate for X-ray data collection were obtained from the MeOH-EtOH (1:1) solutions by slow evaporation at room temperature. Diffraction data were collected at room temperature by the $\omega$-scan technique on an Oxford Diffraction Xcalibur four-circle diffractometer with Eos CCD-detector with graphite-monochromatized $\mathrm{MoK}_{\alpha}$ radiation $(\lambda=0.71073 \AA)$. The data were corrected for Lorentz-polarization as well as for absorption effects [39]. Accurate unit-cell parameters were determined by a least-squares fit of 2312 (1), 5278 (2) and 4313 (3) reflections of highest intensity, chosen from the whole experiment. The structures were solved with SIR92 [40] and refined with the full-matrix least-squares procedure on $\mathrm{F}^{2}$ by SHELXL97 [41]. Scattering factors incorporated in SHELXL97 were used. The function $\Sigma \mathrm{w}\left(\left|\mathrm{F}_{\mathrm{o}}\right|^{2}-\left|\mathrm{F}_{\mathrm{c}}\right|^{2}\right)^{2}$ was minimized, with $\mathrm{w}^{-1}=\left[\sigma^{2}\left(\mathrm{~F}_{\mathrm{o}}\right)^{2}+(\mathrm{A} \cdot \mathrm{P})^{2}+\mathrm{B} \cdot \mathrm{P}\right](\mathrm{P}=[\mathrm{Max}$ $\left.\left.\left(\mathrm{F}_{\mathrm{o}}^{2}, 0\right)+2 \mathrm{~F}_{\mathrm{c}}^{2}\right] / 3\right)$. The final values of $\mathrm{A}$ and $\mathrm{B}$ are listed in Table 1. Anisotropic atomic displacement parameters were refined for all non-hydrogen atoms. The hydrogen atoms were placed in geometrically idealized positions, and refined as rigid groups with their $\mathrm{U}_{\text {iso }}$ 's as 1.2 or 1.5 (methyl) times $\mathrm{U}_{\mathrm{eq}}$ of the appropriate carrier atom. The absolute structure was assigned according to the known parent compounds, and it was additionally confirmed by the values of the Flack parameters [41] (Table 3). Programs XP [42] and Mercury [43] were used for graphic representations, used in figures. Relevant crystal data are listed in Table 1, together with refinement details.

Crystallographic data (excluding structure factors) for the structural analysis have been deposited with the Cambridge Crystallographic Data Centre, Nos. CCDC-851253 (1), CCDC-851254 (2) and CCDC-851255 (3). Copies of this information may be obtained free of charge from: The Director, CCDC, 12 Union Road, Cambridge, CB2 1EZ, UK. Fax: +44(1223)336-033, e-mail:deposit@ccdc. cam.ac.uk, or www: www.ccdc.cam.ac.uk.

Open Access This article is distributed under the terms of the Creative Commons Attribution License which permits any use, distribution, and reproduction in any medium, provided the original author(s) and the source are credited.

\section{References}

1. Etter JF, Lukas R, Benowitz N, West R, Dresler C (2008) Drug Alcohol Depend 92:3

2. Tutka P, Zatoński W (2006) Pharmacol Rep 53:777

3. Polosa R, Benowitz NL (2011) Trends Pharmacol Sci 32:281

4. Cassels BK, Bermúdez I, Dajas F, Abin-Carriquiry JA, Wonnacott S (2005) Drug Discov Today 10:1657

5. Hogg RC, Bertrand D (2004) Curr Drug Target CNS Neurol Disord 3:123 
6. Lloyd GK, Williams M (2000) J Pharmacol Exp Ther 292:461

7. Coe JW, Brooks PR, Vetelino MG, Wirtz MC, Arnold EP, Huang J, Sands SB, Davis TI, Lebel LA, Fox CB, Shrikhande A, Heym JH, Schaeffer E, Rollema H, Lu Y, Mansbach RS, Chambers LK, Rovetti CC, Schulz DW, Tingley FD 3rd, O’Neill BT (2005) J Med Chem 48:3474

8. Hendrickson LM, Zhao-Shea R, Tapper AR (2009) Psychopharmacology 204:563

9. Steensland P, Simms JA, Holgate J, Richards JK, Bartlett SE (2007) Proc Natl Acad Sci USA 104:12518

10. Sajja RK, Rahman S (2011) Progr Neuro-Psychopharmacol Biol Psychiatr 35:257

11. Frigerio F, Haseler CA, Gallagher T (2010) Synlett 729

12. Kozikowski AP, Chellappan SK, Ciao Y, Bajjuri KM, Yuan H, Keller KJ, Petukhov PA (2007) Chem Med Chem 2:1157

13. Chellappan SK, Ciao Y, Tueckmantel W, Keller KJ, Kozikowski AP (2006) J Med Chem 49:2673

14. Houllier N, Gouault S, Lasne M-C, Rouen J (2006) Tetrahedron 62:11679

15. Roger G, Lagnel B, Rouen J, Besret L, Valette H, Demphel S, Gopisetti J, Colon C, Ottaviani M, Wrenn LA, Letchworth SR, Bohme GA, Benavides J, Lasne M-C, Bottlaender M, Dollâe F (2003) Bioorg Med Chem 11:5333

16. Houllier N, Gopisetti JM, Lestage P, Lasne M-C, Rouen J (2010) Bioorg Med Chem Lett 20:6667

17. Canu Boido C, Tasso B, Boido V, Sparatore F (2003) Farmaco 58:265

18. Rouen J, Ragot A, Gouault S, Cahard D, Plaquevent J-C, Lasne M-C (2002) Tetrahedron Asymm 13:1299

19. Imming P, Klaperski P, Stubbs MT, Seitz G, Gundisch D (2001) Eur J Med Chem 36:375

20. Marriére E, Rouden J, Tadino V, Lasne M-C (2000) Org Lett 2:1121

21. Stead D, O’Brien P (2007) Tetrahedron 63:1885
22. Hirschhäuser Ch, Haseler CA, Gallagher T (2011) Angew Chem Int Ed 50:5162

23. Przybył AK, Kubicki M (2011) J Mol Struct 985:157

24. Przybył AK, Nowakowska Z (2011) Rapid Commun Mass Spectrom 25:1193

25. Kálmán A, Argay G, Scharfenberg-Pfeiffer D, Höhne E, Ribár B (1991) Acta Cryst B47:68

26. Kubicki M, Szafrański M (1998) J Mol Struct 446:1

27. Abrahams SC, Keve ET (1971) Acta Cryst A27:157

28. International tables for X-ray crystallography (1974) vol. IV, pp 293-300

29. Katrusiak A, Hoser A, Kałuski Z, Boczoń W (1989) Acta Cryst C45:1758

30. Kubicki M, Borowiak T, Boczoń W (1991) J Crystallogr Spectr Res 21:575

31. Kubicki M, Borowiak T (1989) Acta Cryst C45:1047

32. Pyżalska D, Gdaniec M, Borowiak T, Wolińska-Mocydlarz J (1980) Acta Cryst B36:1602

33. Duax WL, Norton DA (1975) Atlas of Steorid Structures Plenum, New York, pp 16-22

34. Hassel O, Rømming C (1962) Quart Rev Phys Chem 16:1

35. Hassel O (1970) Science 170:497

36. Metrangolo P, Resnati G (2001) Chem Eur J 7:2511

37. Metrangolo P, Neukirch H, Pilati T, Resnati G (2005) Acc Chem Res 38:386

38. Allen FH (2002) Acta Cryst B58:380

39. Agilent (2010) CrysAlis PRO. Agilent Technologies, Yarnton

40. Altomare A, Cascarano G, Giacovazzo C, Gualardi A (1993) J Appl Cryst 26:343

41. Flack HD (1983) Acta Cryst A39:876

42. Sheldrick GM (2008) Acta Cryst A64:112

43. Macrae CF, Bruno IJ, Chisholm JA, Edgington PR, McCabe P, Pidcock E, Rodriguez-Monge L, Taylor R, van de Streek J, Wood PA (2008) J Appl Cryst 41:466 